\title{
Towards a European Defence Union? Military Burden Sharing in the European Union 2006-2013
}

\author{
By Robert Beeres* \\ Myriame Bollen ${ }^{\dagger}$
}

According to the European Council (2013), "Defence matters". However, the extent to which defence does matter appears to vary among the member states. Kollias (2008), analyzing burden sharing and free-riding behaviour of fifteen members of the European Union (EU15) over the year 2001, asks: Suppose the EU15 would create a formal military alliance offering an umbrella of collective defence and security, what member states would be considered over-contributing or under-contributing in providing collective defence and security? Kollias concludes, out of all EU15 members, France, Greece, Italy and the UK would be over-contributing regarding the costs they occur in producing collective military strength if a common European defence came into existence. All other EU countries would be under-contributing compared to the benefits they would enjoy. Our paper aims to revisit Kollias' analysis and to find out, if, nowadays, EU member states would have moved towards each other in the provision of EU-wide defence and security and whether the same would hold regarding the distribution of costs and benefits. We find that over the period 2006-2013 change has occurred. Over this timespan, if united in EDU, Greece would have been considered an under-contributing country, while Germany would count as an over-contributing country.

Keywords: burden sharing, European defence, military expenditures.

\section{Introduction}

As the European Union (EU) does not command community armed forces, military defence of its member states, as well as of some states aspiring to join the EU, remains a sovereign responsibility safeguarded by the North Atlantic Treaty Organization (NATO). Increasingly, however, it is being argued EU should command their own communal armed forces. From this perspective on a common European defence policy, Kollias (2008) analyses the burden sharing and free-riding behaviour of fifteen members of the Union. The analysis by Kollias is underpinned by a state-of-the-art-model to measure burden sharing behaviour amongst differing countries that are members of an military alliance. This model, originally designed by Sandler and Forbes (1980) and evaluated over time, depicts the benefits and costs yielded by cooperation (Khanna and Sandler 1996, 1997, Sandler 2005, Sandler and Shimizu 2014,

\footnotetext{
* Professor, Netherlands Defence Academy, The Netherlands.

${ }^{\dagger}$ Professor, Netherlands Defence Academy, The Netherlands.
} 
Solomon 2004). To date, the model is still being used in research describing and interpreting burden sharing behavior (Beeres and Bollen 2015, Sandler and Shimizu 2014). The novelty Kollias (2008) adds to his research pertains to the fact that this author applies the same model to the EU, thereby regarding the EU as a military alliance ${ }^{1}$. The author asks himself: Suppose the EU15 would create an European Defence Union (EDU) (i.e., a formal EU military alliance offering an umbrella of collective defence and security to its members) what member states could be considered either over-contributors or else, undercontributors in providing collective defence and security? For comparing the EU15's efforts Kollias selected the year 2001

From his research, Kollias concludes out of all EU15 members "France, Greece, Italy and the UK would be overpaying towards the costs of producing the collective EDU military strength if a common European defence came into existence in the form of a formal military alliance producing a public good. All other EU countries would be underpaying compared to the benefits they would enjoy".

Focusing on the development of burden sharing behaviour over the period 2006-2013, and, expanding the number of member states by using data contributed to European Defence Agency, our paper aims to revisit Kollias' research by investigating whether, nowadays, if united in EDU, EU member states could be considered to have moved towards each other in the provision of EU-wide defence and security and, whether the same could be said regarding the distribution of costs and benefits. We have added on to Kollias' original cost indexation by providing data on deployability, sustainability and deployment.

We find that despite our expanded number of EU member states, the extended period of time, and the use of additional data for cost indexation, today as before, Kollias' main results remain standing. If united within EDU, based on our data, France, Italy and the UK would still remain overcontributing countries. However, we find that over the period 2006-2013 change has occurred. During this timespan, if united within EDU, Greece would have evolved into an under-contributing country, while Germany should have to be added to the overpaying countries.

\footnotetext{
${ }^{1}$ In both Kollias' research as well as in our subsequent investigations underpinning this paper, the individual member states' actual expenditures over 2001 and from 2006 until 2013 are used to represent these member states' assumed expenditure patterns if united within EDU.
} 
Table 1. The EU26 in Figures: 2006-2013

\begin{tabular}{|c|c|c|c|c|c|c|c|}
\hline Country & $\begin{array}{c}\text { Area } \\
\left(000 \mathrm{skm}^{2}\right)\end{array}$ & Population (mln) & $\begin{array}{c}\text { GDP cap } \\
(€)\end{array}$ & $\begin{array}{c}\text { Defence } \\
\text { (€mln) }\end{array}$ & $\begin{array}{l}\text { Defence } \\
\text { (\%GDP) }\end{array}$ & Military(\#) & $\begin{array}{c}\text { Deployed } \\
(\#)\end{array}$ \\
\hline Austria & 84 & 8.3 & 34,331 & 2,425 & 0.85 & 28,898 & 1,217 \\
\hline Belgium & 30 & 10.7 & 32,672 & 3,951 & 1.13 & 34,689 & 888 \\
\hline Bulgaria & 111 & 7.6 & 4,565 & 640 & 1.90 & 32,476 & 724 \\
\hline Cyprus & 9 & 0.8 & 21,136 & 320 & 1.92 & 12,340 & 5 \\
\hline Czech Rep & 79 & 10.4 & 13,531 & 1,924 & 1.38 & 24,118 & 1,245 \\
\hline Estonia & 45 & 1.3 & 11,593 & 278 & 1.78 & 3,069 & 229 \\
\hline Finland & 338 & 5.3 & 34,316 & 2,638 & 1.44 & 24,633 & 600 \\
\hline France & 643 & 64.1 & 30,415 & 41,058 & 2.11 & 273,952 & 13,260 \\
\hline Germany & 357 & 81.9 & 30,704 & 32,856 & 1.31 & 233,260 & - \\
\hline Greece & 132 & 11.1 & 19,228 & 4,716 & 2.17 & 125,012 & 1,240 \\
\hline Hungary & 93 & 10.0 & 9,758 & 1,083 & 1.11 & 20,424 & 1,034 \\
\hline Ireland & 70 & 4.4 & 38,359 & 944 & 0.56 & 9,855 & 584 \\
\hline Italy & 301 & 58.7 & 26,278 & 22,025 & 1.43 & 203,642 & 8,089 \\
\hline Latvia & 65 & 2.2 & 9,380 & 249 & 1.24 & 5,011 & 260 \\
\hline Lithuania & 65 & 3.2 & 8,894 & 286 & 1.04 & 8,686 & 268 \\
\hline Luxembourg & 3 & 0.5 & 75,504 & 187 & 0.56 & 1,070 & 42 \\
\hline Malta & 0.3 & 0.4 & 14,768 & 38 & 0.64 & 1,944 & 11 \\
\hline Netherlands & 42 & 16.5 & 35,322 & 8,269 & 1.42 & 45,927 & 2,416 \\
\hline Poland & 313 & 38.2 & 8,975 & 6,069 & 1.77 & 114,160 & 3,077 \\
\hline Portugal & 92 & 10.5 & 15,673 & 2,559 & 1.55 & 36,990 & 640 \\
\hline Romania & 238 & 20.7 & 6,237 & 1,767 & 1.39 & 70,773 & 2,125 \\
\hline Slovakia & 49 & 5.4 & 11,675 & 834 & 1.35 & 14,185 & 606 \\
\hline Slovenia & 20 & 2.0 & 17,215 & 498 & 1.43 & 6,876 & 471 \\
\hline Spain & 505 & 45.5 & 22,998 & 11,272 & 1.08 & 129,527 & 3,557 \\
\hline Sweden & 450 & 9.2 & 38,122 & 4,283 & 1.23 & 15,616 & 864 \\
\hline UK & 244 & 61.8 & 29,441 & 43,659 & 2.41 & 184,375 & 13,909 \\
\hline EU26 & 4,380 & 490.9 & 24,734 & 194,825 & 1.61 & $1,661,505$ & 57,254 \\
\hline
\end{tabular}

Sources: Area: (CIA, 2016); Population: Trading economics (2000-2013); Other variables: EDA (2016). 


\section{EU in Defence Economic Terms}

According to the European Council (2013), "Defence matters". However, the extent to which defence does matter appears to vary among the member states. To provide a closer look into this diversity Table 1 summarizes data on defence expenditures as well as on surface area, population and GDP for 26 out of 28 EU member states. Croatia has not been included in this table as this country only joined the EU in 2013. As for Denmark, this country does not contribute data to the European Defence Agency (EDA) needed to feed into columns 4 until 8 in Table 1. As mentioned above, Table 1 presents the average results over the period 2006-2013. In line with Kollias (2008), columns 2, 3 and 4 offer insight into the countries' surface area, its inhabitants and its wealth. Columns 5-8, over the same period, provide information on the countries' absolute defence expenditures, defence expenditures as a percentage of the GDP as well as on the numbers of military employed and deployed.

When measuring wealth based on GDP per capita and the defence burden by applying the ratio D/GDP, from Table 1 it follows that, over the period 2006-2013, Europe's wealthiest country, Luxembourg, with a GDP per capita amounting to $€ 75,504$, carries the lowest defence burden, namely 0.56 per cent of its GDP. Europe's poorest country, Bulgaria, $€ 4,484$ per capita, on the other hand, from 20062013, spends almost 2 percent of its GDP on defence, thereby approaching countries, such as the UK, France and Greece. On average, these three latter countries spend over 2 per cent of their GDP on defence. When calculating absolute defence expenditures, over the same timespan, the UK and France have spent most. For this reason both countries are acknowledged regional superpowers.

However, taken on their own, statistics, on GDP en D/GDP fall short when it comes to comparing differences in performance as the outcomes of any comparisons based on these statistics will always be influenced strongly by differences in wealth between countries. The question whether Bulgaria actually performs better than Luxembourg, or vice versa, therefore, requires an additional set of variables to be taken into account, for instance, by relating the number of deployable military per country to the total number of active military employed. As Table 1 shows, in case of Bulgaria, this calculation adds up to 2 per cent $(724 / 32,476)$, whereas, for Luxembourg to almost 4 per cent $(42 / 1,070)$. In general, it may be concluded that "in assessing the relative performance of EU member states the selection of specific measures or sets of performance measures does make a difference" (Beeres and Bogers 2012:14).

Moreover, as Kollias (2008) argues, there are numerous other motives for countries to spend differing numbers of resources on defence. For one, the availability of nuclear capacity, in the case of the UK and France; or else a domestic defence industry in the case of the UK, France, Germany, Italy and Sweden and even a strong orientation on import and export will impact the levels of defence expenditures in various EU countries. As for Germany, it should be noted that in Table 1 the number of military deployed is lacking as this data is not been made available by EDA. 


\section{Measuring Burden Sharing: Matching Costs and Benefits}

\section{Costs of Military Strength}

Following Kollias' footsteps in mapping burden sharing behaviour within the $\mathrm{EU}$, first, we assume the existence of an EDU, i.e. a formal military alliance offering an umbrella of collective defence and security to its members (Kollias 2008: 257). Second, for each country, we calculate an Average Benefit Share index (ABS) to be compared to its Burden Share Index (BSI).

Table 2. Relative Costs of Collective Military Strength 2006-2013

\begin{tabular}{|l|c|c|c|c|c|}
\hline Country & $\begin{array}{c}\text { BSI-1 } \\
\text { Defence } \\
\text { spending }\end{array}$ & Deployability & Sustainability & Deployment & $\begin{array}{c}\text { BSI-2 } \\
\text { Deployability } \\
\text { Sustainability } \\
\text { Deployment }\end{array}$ \\
\hline Austria & 1.24 & 0.51 & 0.96 & 2.13 & 1.20 \\
\hline Belgium & 2.03 & 1.90 & 1.88 & 1.55 & 1.78 \\
\hline Bulgaria & 0.33 & 1.45 & 1.19 & 1.26 & 1.30 \\
\hline Cyprus & 0.16 & 0.06 & 0.00 & 0.01 & 0.02 \\
\hline Czech Rep & 0.99 & 1.76 & 1.26 & 2.18 & 1.73 \\
\hline Estonia & 0.14 & 0.17 & 0.22 & 0.40 & 0.26 \\
\hline Finland & 1.35 & 0.75 & 1.29 & 1.07 & 1.04 \\
\hline France & 21.07 & 22.50 & 27.08 & 23.16 & 24.24 \\
\hline Germany & 16.86 & - & - & - & - \\
\hline Greece & 2.42 & 6.00 & 3.30 & 2.17 & 3.82 \\
\hline Hungary & 0.56 & 0.71 & 1.06 & 1.81 & 1.19 \\
\hline Ireland & 0.48 & 0.23 & 0.86 & 1.02 & 0.70 \\
\hline Italy & 11.30 & 15.64 & 13.30 & 14.30 & 14.41 \\
\hline Latvia & 0.13 & 0.21 & 0.17 & 0.28 & 0.22 \\
\hline Lithuania & 0.15 & 0.34 & 0.33 & 0.45 & 0.37 \\
\hline Luxembourg & 0.10 & 0.07 & 0.05 & 0.07 & 0.06 \\
\hline Malta & 0.02 & 0.03 & 0.03 & 0.02 & 0.03 \\
\hline Netherlands & 4.24 & 4.79 & 3.57 & 4.22 & 4.19 \\
\hline Poland & 3.12 & 3.95 & 3.27 & 5.37 & 4.20 \\
\hline Portugal & 1.31 & 2.18 & 2.02 & 1.12 & 1.77 \\
\hline Romania & 0.91 & 2.28 & 2.79 & 3.71 & 2.92 \\
\hline Slovakia & 0.43 & 0.78 & 0.72 & 1.06 & 0.75 \\
\hline Slovenia & 0.26 & 0.60 & 0.44 & 0.82 & 0.85 \\
\hline Spain & 5.79 & 12.42 & 7.24 & 6.21 & 8.62 \\
\hline Sweden & 2.20 & 0.87 & 1.79 & 1.51 & 1.39 \\
\hline UK & 22.41 & 19.79 & 25.19 & 24.29 & 23.09 \\
\hline Source & & & & \\
\hline
\end{tabular}

Source: EDA 2016

For BSI, Kollias used the contributions by each member to the costs of the common European defence. The author then calculated the total costs of EU defence to be the sum of the defence expenditures contributed by all countries. In Table 2 this index is represented by the second column (BSI-1). Taking Austria as an example, Table 2 (second column) should be interpreted as follows. As a percentage, the 
column defence spending expresses the amount of money spent on defence by a specific country as compared to all other countries. Austria, from 2006-2013, on average, spent $€ 2,425$ million (see Table 1), whereas, Table 1 also shows the average sum total spent by all other EU countries to equal $€ 194,825$ (EU26). This, then, leads to a "score" of $1.24(2,425 / 194,825)$ for Austria. Regarding deployability, sustainability and deployment (columns 3, 4 and 5 of Table 2) over the same period, we have collected and calculated EDA data accordingly.

As to the sixth column in Table 2, index BSI-2, some additional explanation is indicated here. BSI-2 presents a second burden sharing index, next to BSI-1, and is underpinned by both the EU countries' mean deployability and sustainability as well as by their actual deployments (Beeres and Bogers 2012: 5, Bogers and Beeres 2013: 37). BSI-2, arguably, expresses more fully (1) to what extent money allocated to defence will be transformed into deployable military, and (2) to what extent governments and politicians are prepared to actually deploy their military. Therefore, as compared to BSI1 , according to us, BSI-2 expresses more fully the actual economic costs of military strength. Germany, however, does not publish data on deployability, sustainability and deployment of its armed forces, and for this reason, cannot be included in BSI-2. Consequentially, Table 2 comprises both BSI-1 and BSI- 2 .

Table 3, over the period 2006-2013, presents correlations between the variables defence spending, deployability, sustainability and deployment resulting from applying the Spearman rank correlation test. Table 3 comprises all individual values per variable pertaining to all individual countries, from 2006-2013, in so far as these were simultaneously available.

Table 3. Spearman Correlations between Defence Burden Measures $(n=161)$

\begin{tabular}{|l|c|c|c|c|}
\hline & Expenditures & Deployability & Sustainability & Deployment \\
\hline Expenditure & 1.000 & $0.865^{* * *}$ & $0.895^{* * *}$ & $0.863^{* * *}$ \\
\hline Deployability & & 1.000 & $0.924^{* * *}$ & $0.864^{* * *}$ \\
\hline Sustainability & & & 1.000 & $0.881^{* * *}$ \\
\hline Deployment & & & & 1 \\
\hline
\end{tabular}

$* * *, * *, *$ represent statistical significance at 1\%, 5\% and 10\% level, respectively (two-tailed test) Source: EDA (2016).

Based on Table 3, correlations between the four variables can be characterized a very strong positive association (Davis 1971: 49) and, therefore, it does not really matter what variables are selected as a burden index. On these grounds, we have decided to continue this research by using BSI-1, thereby allowing us to keep Germany within our dataset.

\section{Benefits of Military Strength}

The so called joint product model (Sandler 1977, Sander and Forbes 1980, Murdoch and Sandler 1982, Sandler and Shimizu 2014) presumes, within an alliance, the countries' defence expenditures not only to result in pure public benefits (i.e., deterrence), but, also, to contribute to country-specific private benefits (e.g., national disaster relief) as well as impure public protective benefits (e.g., armoured vehicles). As the share of excludable benefits (i.e., impure public- and country specific private benefits) increases, according to the joint product model, defence burdens are expected to match defence benefits (Sandler and Shimizu 2014). 
Table 4 summarizes various benefits distinguished in our research. As to the variables Area, Population, GDP, Imports and Exports, these are derived from Kollias, whereas, Terrorism has been inspired by Sandler and Shimizu (2014). Next, we will compare the countries' BSI-1 to three differing Average Benefit Shares (ABS). First, we compare ABS to BSI-1, in which:

(1) $\mathrm{ABS}=\mathrm{f}$ (Area; Population; GDP).

We then calculate each country's percentages on the variables mentioned above, subsequently, divided by three. Next, we extend our analysis to:

(2) $\mathrm{ABS}=\mathrm{f}$ (Area; Population; GDP; Import; Export).

We then proceed to calculate each country's percentages on the variables mentioned above, subsequently divided by five. Last, we add the variable Terrorism:

(3) $\mathrm{ABS}=\mathrm{f}$ (Area; Population; GDP; Import; Export; Terrorism).

Table 4. Relative Benefits of Military Strength 2006-2013

\begin{tabular}{|l|c|c|c|c|c|c|}
\hline Country & Area & Population & GDP & Imports & Exports & Terrorism \\
\hline Austria & 1.91 & 1.70 & 2.35 & 3.06 & 3.01 & 4.08 \\
\hline Belgium & 0.69 & 2.19 & 2.89 & 7.62 & 8.03 & 1.60 \\
\hline Bulgaria & 2.53 & 1.54 & 0.28 & 0.54 & 0.41 & 3.06 \\
\hline Cyprus & 0.21 & 0.16 & 0.14 & 0.15 & 0.03 & 2.42 \\
\hline Czech Rep & 1.80 & 2.12 & 1.16 & 2.34 & 2.55 & 2.61 \\
\hline Estonia & 1.03 & 0.27 & 0.13 & 0.28 & 0.24 & 0.53 \\
\hline Finland & 7.72 & 1.09 & 1.51 & 1.40 & 1.45 & 0.49 \\
\hline France & 14.70 & 13.05 & 16.05 & 11.75 & 10.35 & 8.46 \\
\hline Germany & 8.15 & 16.69 & 20.72 & 19.99 & 24.74 & 4.44 \\
\hline Greece & 3.01 & 2.27 & 1.77 & 1.29 & 0.53 & 15.97 \\
\hline Hungary & 2.21 & 2.04 & 0.81 & 1.71 & 1.82 & 1.65 \\
\hline Ireland & 1.60 & 0.90 & 1.40 & 1.28 & 2.21 & 6.10 \\
\hline Italy & 6.88 & 11.96 & 12.71 & 9.02 & 9.01 & 7.66 \\
\hline Latvia & 1.47 & 0.44 & 0.71 & 0.27 & 0.20 & 0.00 \\
\hline Lithuania & 1.49 & 0.65 & 0.23 & 0.49 & 0.43 & 0.00 \\
\hline Luxembourg & 0.06 & 0.10 & 0.30 & 0.51 & 0.41 & 0.00 \\
\hline Malta & 0.01 & 0.08 & 0.05 & 0.10 & 0.07 & 0.00 \\
\hline Netherlands & 0.95 & 3.36 & 4.79 & 9.67 & 11.03 & 4.45 \\
\hline Poland & 7.14 & 7.78 & 2.82 & 3.30 & 3.03 & 0.00 \\
\hline Portugal & 2.10 & 2.15 & 1.36 & 1.43 & 1.00 & 0.82 \\
\hline Romania & 5.44 & 4.21 & 1.06 & 1.24 & 0.93 & 0.21 \\
\hline Slovakia & 1.12 & 1.10 & 0.52 & 1.23 & 1.26 & 0.00 \\
\hline Slovenia & 0.46 & 0.41 & 0.29 & 0.57 & 0.57 & 0.00 \\
\hline Spain & 11.54 & 9.27 & 8.62 & 6.43 & 5.02 & 14.04 \\
\hline Sweden & 10.28 & 1.88 & 2.90 & 2.79 & 3.10 & 4.62 \\
\hline UK & 5.56 & 12.58 & 14.97 & 11.56 & 8.56 & 16.81 \\
\hline Sourcs: Are & 2016,9 & & & & \\
\hline
\end{tabular}

Sources: Area (CIA 2016), Population:Trading economics (2000-2013), GDP: EDA (2016), Imports \& Exports: Eurostat (2013), Terrorism: Institute for Economics and Peace (2014). 
Finally, we proceed to calculate each country's percentages on the variables mentioned above, subsequently divided by six.

Following Kollias (2008: 258), we hold, "If the ABS is greater than the BSI then one may conclude that in such a case this ally yields more benefits than its contribution to the joint defence effort. Therefore, it has a positive net benefit (NB)". These countries are called under-contributing countries. Kollias continues, "The reverse, of course, is the case if the ABS is smaller than the BSI, whereby this would yield a negative NB". These countries are called over-contributing countries.

\section{Results}

For each of 26 EU member states, from 2006 until 2013, Table 5 presents the average values of ABS, BSI as well as their Net Benefit (NB). Out of these 26 assumed members to a future EDU, for seven countries - Belgium, France, Germany, Greece, Italy, the Netherlands and the UK we calculate negative net benefits (NB = $0.11 ;-7.10 ;-1.67 ;-0.07 ;-0.78 ;-1.21 ;-11.37)$. In his original paper, based on data from 2001, out of 15 assumed members to a future EDU, Kollias calculated negative net benefits for six countries. Quoting Kollias (2008), "Denmark, France, Greece, Italy, The Netherlands and the UK appear from the estimations to yield negative net benefits (NB $=-0.01 ;-6.00 ;-0.99 ;-1.90 ;-0.59 ;-9.00$ respectively) albeit one of them - Denmark $(\mathrm{NB}=-0.01)$ - only marginally". As explained before, and in contrast to Kollias, we were unable to include Denmark in our research. Having said so, as Table 5 shows, findings based on Kollias' original research to a large extent are corroborated by our own, the exception being Germany that from 2006 until 2013 has turned into an over-contributing country.

Table 6 is presented to offer a closer look at developments in net benefits across the 26 EU member states from 2006 until 2013. Based on Table 6, over the period 2006 until 2013, four categories of burden sharing behaviour can be distinguished. First, the largest category is made up by countries showing constantly undercontributing behaviour (19): Austria, Bulgaria, Cyprus, Czech Republic, Estonia, Finland, Hungary, Ireland, Latvia, Lithuania, Luxembourg, Malta, Poland, Portugal, Romania, Slovakia, Slovenia, Spain, and Sweden. The second category consists of constantly over-contributing counties (4): France, Italy, The Netherlands and the UK (although the extent to which these countries show over-contributing behaviour appears to decrease). Third, two countries, Belgium en Germany, have moved from being under-contributors to over-contributors, whereas, finally, Greece has moved from an over-contributing to an under-contributing country. 
Table 5. Contribution to an EDU's Burdens and Benefits (2006-2013)

\begin{tabular}{|l|c|c|c|}
\hline Country & $\begin{array}{c}\text { Average Benefit Share } \\
\text { (ABS) }\end{array}$ & $\begin{array}{c}\text { Burden Share Index } \\
\text { (BSI-1) }\end{array}$ & $\begin{array}{c}\text { Net Benefit } \\
\text { (NB) }\end{array}$ \\
\hline Austria & 1.99 & 1.24 & 0.75 \\
\hline Belgium & 1.92 & 2.03 & -0.11 \\
\hline Bulgaria & 1.45 & 0.33 & 1.12 \\
\hline Cyprus & 0.17 & 0.16 & 0.01 \\
\hline Czech Rep & 1.69 & 0.99 & 0.70 \\
\hline Estonia & 0.48 & 0.14 & 0.34 \\
\hline Finland & 3.44 & 1.35 & 2.09 \\
\hline France & 14.60 & 21.07 & -7.10 \\
\hline Germany & 15.19 & 16.86 & -1.67 \\
\hline Greece & 2.35 & 2.42 & -0.07 \\
\hline Hungary & 1.69 & 0.56 & 1.13 \\
\hline Ireland & 1.30 & 0.48 & 0.82 \\
\hline Italy & 10.52 & 11.30 & -0.78 \\
\hline Latvia & 0.87 & 0.13 & 0.74 \\
\hline Lithuania & 0.79 & 0.15 & 0.64 \\
\hline Luxembourg & 0.15 & 0.10 & 0.05 \\
\hline Malta & 0.05 & 0.02 & 0.03 \\
\hline Netherlands & 3.03 & 4.24 & -1.21 \\
\hline Poland & 5.91 & 3.21 & 2.79 \\
\hline Portugal & 1.87 & 1.31 & 0.56 \\
\hline Romania & 4.57 & 0.91 & 2.66 \\
\hline Slovakia & 0.91 & 0.43 & 0.48 \\
\hline Slovenia & 0.39 & 0.26 & 0.13 \\
\hline Spain & 9.81 & 5.79 & 4.04 \\
\hline Sweden & 5.02 & 2.20 & 2.82 \\
\hline UK & 11.04 & 22.41 & -11.37 \\
\hline Sarces: & Pops & 0.42 & $(2016)$ \\
\hline
\end{tabular}

Sources: ABS: Area: CIA (2016); Population:Trading economics 2000-2013; GDP: EDA (2016), BSI-1: EDA (2016).

At this point, and in line with Kollias (2008), we broaden our analysis to encompass an international economy dimension. Kollias (2008: 259) argues "that the alliance's military capabilities not only offer an umbrella of protection of wealth produced within the national territory but protect, through the projection of force and military missions abroad, the flow of income and resources to and from the homeland" - in this case the EU. The protection of economic interests abroad is, from such a perspective, an important function of any military alliance. To this effect, we have included international trade -exports and imports - in our analysis. Over the period 2006-2013, Table 7 presents the resulting based on the average values of ABS-variables Area, Population, GDP, Imports, Exports as well as BSIvariable Defence Expenditure. 
Table 6. Development Net Benefit EU Countries (Population, Area, GDP)

\begin{tabular}{|l|c|c|c|c|c|c|}
\hline Country & $\mathbf{2 0 0 6}$ & $\mathbf{2 0 0 8}$ & $\mathbf{2 0 1 0}$ & $\mathbf{2 0 1 1}$ & $\mathbf{2 0 1 2}$ & $\mathbf{2 0 1 3}$ \\
\hline Austria & 0.91 & 0.70 & 0.73 & 0.72 & 0.70 & 0.71 \\
\hline Belgium & 0.10 & -0.22 & -0.11 & -0.14 & -0.22 & -0.15 \\
\hline Bulgaria & 1.16 & 1.06 & 1.13 & 1.17 & 1.15 & 1.11 \\
\hline Cyprus & 0.01 & 0.02 & -0.01 & -0.01 & 0.00 & 0.02 \\
\hline Czech Rep & 0.68 & 0.65 & 0.67 & 0.77 & 0.84 & 0.84 \\
\hline Estonia & 0.38 & 0.33 & 0.35 & 0.33 & 0.30 & 0.29 \\
\hline Finland & 2.29 & 2.22 & 2.04 & 2.05 & 1.93 & 1.91 \\
\hline France & -7.13 & -7.98 & -5.62 & -5.55 & -6.18 & -6.53 \\
\hline Germany & 0.07 & -0.64 & -2.12 & -2.49 & -2.09 & -2.89 \\
\hline Greece & -0.26 & -0.65 & -0.06 & 0.43 & 0.52 & 0.58 \\
\hline Hungary & 1.14 & 1.04 & 1.13 & 1.13 & 1.09 & 1.14 \\
\hline Ireland & 0.88 & 0.80 & 0.80 & 0.81 & 0.80 & 0.79 \\
\hline Italy & -2.64 & -0.71 & -0.62 & -0.88 & -0.55 & -0.45 \\
\hline Latvia & 0.57 & 0.52 & 0.59 & 0.58 & 0.58 & 0.57 \\
\hline Lithuania & 0.66 & 0.60 & 0.66 & 0.66 & 0.65 & 0.65 \\
\hline Luxembourg & 0.05 & 0.01 & 0.06 & 0.06 & 0.08 & 0.08 \\
\hline Malta & 0.03 & 0.03 & 0.02 & 0.03 & 0.03 & 0.03 \\
\hline Netherlands & -1.05 & -1.17 & -1.31 & -1.22 & -1.26 & -1.12 \\
\hline Poland & 3.37 & 2.99 & 2.64 & 2.51 & 2.37 & 2.36 \\
\hline Portugal & 0.66 & 0.61 & 0.46 & 0.47 & 0.59 & 0.45 \\
\hline Romania & 2.68 & 2.68 & 2.72 & 2.65 & 2.65 & 2.55 \\
\hline Slovakia & 0.50 & 0.42 & 0.48 & 0.53 & 0.51 & 0.53 \\
\hline Slovenia & 0.14 & 0.11 & 0.09 & 0.14 & 0.16 & 0.18 \\
\hline Spain & 3.97 & 3.55 & 4.16 & 4.55 & 4.00 & 4.55 \\
\hline Sweden & 2.81 & 2.94 & 2.81 & 2.83 & 2.68 & 2.64 \\
\hline UK & -11.96 & -9.92 & -11.68 & -12.15 & $-11,35$ & -10.82 \\
\hline Sources Net Bne & -145 & \\
\hline
\end{tabular}

Sources: Net Benefits, own calculations based on: CIA (2016), Trading economics (2000-2013), EDA (2016).

Based on Table 7, we can now conclude, the first category of countries constantly displaying under- contributing burden sharing behaviour is to be enlarged by Belgium and The Netherlands, and amounts to 21 . The category of countries constantly displaying over- contributing behaviour (3) decreases by one, now including France, Italy and the UK. Third, there remains one country, Germany that has developed from an under-contributor to an over-contributor, whereas, finally, Greece has developed from a country showing over-contributing behaviour into the reverse. 
Table 7. Development Net Benefits EU Countries (Population, Area, GDP, Import, Export)

\begin{tabular}{|l|c|c|c|c|c|c|}
\hline Country & $\mathbf{2 0 0 6}$ & $\mathbf{2 0 0 8}$ & $\mathbf{2 0 1 0}$ & $\mathbf{2 0 1 1}$ & $\mathbf{2 0 1 2}$ & $\mathbf{2 0 1 3}$ \\
\hline Austria & 1.32 & 1.14 & 1.15 & 1.14 & 1.10 & 1.12 \\
\hline Belgium & 2.49 & 2.17 & 2.22 & 2.20 & 2.09 & 2.91 \\
\hline Bulgaria & 0.73 & 0.68 & 0.73 & 0.79 & 0.78 & 0.75 \\
\hline Cyprus & -0.02 & -0.01 & -0.04 & -0.04 & -0.04 & -0.02 \\
\hline Czech Rep & 0.85 & 0.93 & 0.99 & 1.13 & 1.19 & 1.20 \\
\hline Estonia & 0.29 & 0.24 & 0.25 & 0.25 & 0.23 & 0.21 \\
\hline Finland & 1.56 & 1.47 & 1.20 & 1.22 & 1.07 & 1.04 \\
\hline France & -8.04 & -9.33 & -7.08 & -7.04 & -7.68 & -8.10 \\
\hline Germany & 2.81 & 2.16 & 0.80 & 0.46 & 0.81 & -0.04 \\
\hline Greece & -0.84 & -1.23 & -0.65 & -0.17 & -0.04 & 0.03 \\
\hline Hungary & 1.15 & 1.10 & 1.18 & 1.18 & 1.13 & 1.19 \\
\hline Ireland & 1.14 & 0.97 & 0.98 & 0.94 & 0.91 & 0.89 \\
\hline Italy & -3.13 & $-1,21$ & -1.22 & -1.51 & -1.25 & -1.21 \\
\hline Latvia & 0.37 & 0.33 & 0.39 & 0.40 & 0.42 & 0.41 \\
\hline Lithuania & 0.48 & 0.47 & 0.52 & 0.54 & 0.55 & 0.56 \\
\hline Luxembourg & 0.21 & 0.17 & 0.17 & 0.16 & 0.18 & 0.18 \\
\hline Malta & 0.04 & 0.04 & 0.04 & 0.04 & 0.05 & 0.04 \\
\hline Netherlands & 1.59 & 1.71 & 1.71 & 1.75 & 1.87 & 1.95 \\
\hline Poland & 2.08 & 1.88 & 1.57 & 1.45 & 1.33 & 1.36 \\
\hline Portugal & 0.41 & 0.37 & 0.19 & 0.19 & 0.31 & 0.17 \\
\hline Romania & 1.61 & 1,65 & 1.74 & 1.69 & 1.69 & 1.60 \\
\hline Slovakia & 0.53 & 0.54 & 0.62 & 0.68 & 0.69 & 0.73 \\
\hline Slovenia & 0.19 & 0.19 & 0.16 & 0.22 & 0.23 & 0.26 \\
\hline Spain & 2.54 & 1.94 & 2.45 & 2.88 & 2.31 & 2.92 \\
\hline Sweden & 2.04 & 2.14 & 2.00 & 1.99 & 1.80 & 1.73 \\
\hline UK & -11.96 & -10.52 & -12.08 & $-12,54$ & -11.73 & -11.18 \\
\hline Sources: & & & & & \\
\hline
\end{tabular}

Sources: Net benefits, own calculations based on: CIA (2016), Trading Economics (2000-2013), EDA (2016); and Eurostat (2013).

Inspired by Sandler and Shimizu (2014), we have decided to add the variable of Terrorism to ABS. To this end, data provided in the Global Terrorism Index (2012) published by the Institute for Economics and Peace has been used. Table 8 shows the effects of including Terrorism as a variable. Our terrorism index is based on the Global Terrorism Index (GTI), designed by the Institute for Economics and Peace. Annually, on behalf of countries worldwide, GTI calculates an index based on the following variables: (1) total number of terrorist attacks in a given year, (2) total number of fatalities due to terrorist attacks in a given year, (3) total number of injuries due to terrorist attacks in a given year and (4) total property damage due to terrorist attacks in a given year. As a result from these calculations, the countries' scores may vary from a maximum GTI score of 10 (highest impact of terrorism) to 0 (no impact of terrorism). By summation of individual scores for EU countries in a given year, and, consecutively, dividing individual GTI scores by the sum total of all EU member states, we have transferred GTI scores into the proxy Terrorist Threat. In this way, it becomes possible to add the impact of terrorism to the model as a percentage, in the same way as the other variables. The impact of adding this variable can be illustrated for Greece. Within the EU, Greece finds itself amongst countries with the highest GTI scores (2006: 4.36; 2008: 4.53; 2010: 5.04; 2012: 4.29; 2013: 4.73). 
Within our model, these scores are translated into the following percentages (2006: 15.94; 2008: 15.70; 2010: 17.98; 2012: 13.83; 2013: 15.91). In this way, also, when comparing Tables 7 and 8, differences in Greece's burden sharing behavior can be explained. When including Terrorism in the calculations of net benefits, it appears, four countries -France, Germany, Italy, and the UK- have obtained negative net benefits.

All in all, we conclude, from 2006 until 2013, the EU member states' burden sharing behaviour for the most part to be quite consistent. Amongst the $26 \mathrm{EU}$ countries there appears little to none convergence in burden sharing behaviour. A remarkable finding concerns Greece's transformation into an under-contributing country. This transformation is due to the financial crisis that struck Greece from 2009, as can be seen from a decrease in defence expenditures dropping from $€ 6.2$ billion in the year 2008 to $€ 3.1$ billion in 2013 (EDA 2015). As to Germany, the opposite appears to occur, as can be noticed from an increase in defence expenditures from 2008, $€ 31.7$ billion to 2013 when $€ 33.8$ billion were spent. Last, we would like to draw attention to Malta being the single EU country to "score" most consistently, marginally positive, across all tables, suggesting the former Crusaders' island to be almost totally devoid of free riding behaviour!

Table 8. Development Net Benefits EU Countries (Population, Area, GDP, Import, Export, Terrorist Threat)

\begin{tabular}{|l|c|c|c|c|c|c|}
\hline Country & $\mathbf{2 0 0 6}$ & $\mathbf{2 0 0 8}$ & $\mathbf{2 0 1 0}$ & $\mathbf{2 0 1 1}$ & $\mathbf{2 0 1 2}$ & $\mathbf{2 0 1 3}$ \\
\hline Austria & 1.05 & 1.91 & 1.72 & 1.55 & 1.06 & 0.85 \\
\hline Belgium & 2.05 & 1.59 & 1.60 & 1.53 & 2.03 & 1.77 \\
\hline Bulgaria & 0.59 & 0.59 & 0.58 & 1.03 & 2.29 & 2.02 \\
\hline Cyprus & 0.05 & 0.79 & -0.01 & -0.04 & 0.03 & 1.24 \\
\hline Czech Rep & 0.56 & 1.65 & 1.14 & 1.08 & 0.99 & 1.31 \\
\hline Estonia & 0.23 & 0.17 & 0.19 & 0.59 & 0.32 & 0.23 \\
\hline Finland & 1.11 & 1.36 & 0.85 & 0.82 & 0.66 & 0.61 \\
\hline France & -9.03 & -10.10 & -8.12 & -8.24 & -8.21 & -8.79 \\
\hline Germany & 0.14 & -0.17 & -1.51 & -1.51 & -1.28 & -2.49 \\
\hline Greece & 1.51 & 1.08 & 2.04 & 2.15 & 1.98 & 2.40 \\
\hline Hungary & 0.87 & 1.21 & 1.38 & 1.10 & 0.95 & 0.95 \\
\hline Ireland & 1.71 & 1.58 & 1.46 & 2.21 & 2.26 & 2.40 \\
\hline Italy & -2.95 & -2.14 & -1.42 & -2.03 & -1.45 & -1.33 \\
\hline Latvia & 0.29 & 0.24 & 0.31 & 0.32 & 0.33 & 0.32 \\
\hline Lithuania & 0.38 & 0.36 & 0.41 & 0.43 & 0.44 & 0.44 \\
\hline Luxembourg & 0.16 & 0.13 & 0.13 & 0.12 & 0.14 & 0.13 \\
\hline Malta & 0.03 & 0.03 & 0.03 & 0.03 & 0.03 & 0.03 \\
\hline Netherlands & 0.92 & 1.03 & 1.97 & 1.92 & 1.53 & 1.26 \\
\hline Poland & 1.33 & 1.07 & 0.76 & 0.64 & 0.51 & 0.53 \\
\hline Portugal & 0.14 & 0.10 & -0.08 & 0.58 & 0.30 & 0.04 \\
\hline Romania & 1.20 & 1.34 & 1.35 & 1.28 & 1.27 & 1.17 \\
\hline Slovakia & 0.38 & 0.37 & 0.44 & 0.50 & 0.50 & 0.55 \\
\hline Slovenia & 0.12 & 0.12 & 0.09 & 0.14 & 0.16 & 0.18 \\
\hline Spain & 5.19 & 3.39 & 3.34 & 3.30 & 2.24 & 2.61 \\
\hline Sweden & 2.10 & 1.91 & 2.57 & 2.28 & 2.04 & 1.62 \\
\hline UK & -10.10 & -9.62 & -11.21 & -11.68 & -11.13 & -10.07 \\
\hline Sources & 5.625 & & & & \\
\hline
\end{tabular}

Sources: Net benefits, own calculations based on: CIA (2016); Trading economics (2000-2013); EDA (2016); Eurostat (2013); and Institute for Economics and Peace (2014). 


\section{Conclusions}

In our paper we set out to revisit Kollias' (2008) research by investigating, if united in EDU, nowadays, EU member states would have moved towards each other in providing EU-wide defence and security and whether the same would hold true for the distribution of costs and benefits between them. To this end, we followed Kollias' footsteps in assuming the existence of an EDU (i.e., a formal military alliance offering an umbrella of collective defence and security to its members). To map the burden sharing behaviour of states participating in EDU we distinguished two indices: one pertaining to costs and the other to benefits. Assuming EDU would actually exist, the benefit index expresses benefits any EU member state would enjoy by the provision of collective defence and security. Under similar conditions, the cost index expresses burdens for each EU country to bear in providing collective defence and security.

Compared to Kollias, we have increased the number of EU countries in our analysis by 11 (from EU15 to EU26). Also, instead of analyzing the indices over a period of one year, as Kollias did based on the statistics of 2001, we have based our analysis over a period ranging from 2006 to 2013. Thirdly, we added on to Kollias' original cost indexation by providing data on deployability, sustainability and deployment.

We find that despite our expanded number of EU member states, the extended period of time, and the use of additional data for cost indexation, today as before, Kollias' main results remain standing. France, Italy and, the UK, now joined by Germany, would be overpaying towards the costs of producing collective EDU military strength if such a common umbrella organization providing the public good European defence were to come into existence. All other EU countries would still be considered underpaying compared to the benefits they would enjoy ${ }^{1}$.

In other words, from 2001 until 2013, progress in the field of putting together a collective European Defence appears to have been sadly lagging behind. To some extent, this standstill may be explained by the effects of the global recession resulting from the credit crunch, but having said so, during this specific decade, with major security problems happening seemingly overnight in the EU's backyard, it seems inevitable for the discussion on the need for EU communal forces to rekindle.

Terrorism, in particular, constitutes a variable in between external and internal security. Increasingly, external and internal security issues have become intertwined. We, therefore, suggest to elaborate on Kollias' research further by incorporating variables reflecting today's EU problems, incorporating the refugees crisis and ensuing problems, such as, human trafficking and irregular migration cross-border criminality, cyber-attacks, as well as internal and external border guarding.

\footnotetext{
${ }^{1}$ Looking more comprehensively across EU member states, regarding their burden sharing behavior within NATO, from 2006-2013, with the exception of the UK, all remaining EU member states can be characterized to be underpaying nations (Beeres and Bollen, 2016).
} 


\section{References}

Beeres R, Bogers M (2012) Ranking European Armed Forces. Defence and Peace Economics 23(1): 1-16.

Beeres R, Bollen M (2015) Exciting Dilemma: A Defence Economics View on a US Exit from NATO. In The Dilemma of Leaving: Political and Military Exit Strategies (NL ARMS 2015), J Nöll, D Van den Wollenberg, F Osinga, G Frerks, I Van Kemenade (Eds), 271-298. The Hague: Asser Press.

Bogers M, Beeres R (2013) Mission Afghanistan: Who Bears the Heaviest Burden? Peace Economics, Peace Science and Public Policy 19(1): 32-55.

CIA (2016) The World Factbook. Retrieved from http://bit.ly/2cJaCil. [Accessed 21 February 2016].

Davis JA (1971) Elementary Survey Analysis. Englewood Cliffs, N.J: Prentice-Hall.

EDA (2016) Defence Data Portal. Retrieved from http://bit.ly/2cAoRsN. [Accessed 21 February 2016].

European Council (2013) 19/20 December Conclusions. EUCO 217/13, Brussels. Retrieved from http://bit.ly/2cStL5W. [Accessed 21February 2016].

Eurostat (2013) Total import and exports of goods. Retrieved from http://bit.ly/1eKIdTj. [Accessed 30May 2014].

IISS 2006-2016 The Military Balance 2006-2016. London: Routledge.

Institute for Economics and Peace (2014) Global Terrorism Index. Retrieved from http://bit. 1y/2c5z2RE. [Accessed 30May 2014].

Khanna J, Sandler T (1996) NATO Burden Sharing 1960-1992. Defence and Peace Economics 7(2): 115-133.

Khanna J, Sandler T (1997) Conscription, Peacekeeping, and Foreign Assistance: NATO Burden Sharing in the Post-Cold War Era. Defence and Peace Economics 8(1): 101121.

Kollias C (2008) A Preliminary Investigation of the Burden Sharing Aspects of a European Union Common Defence Policy. Defence and Peace Economics 19(4): 253-263.

Sandler T (2005) NATO Benefits, Burdens and Borders: Comment. Defence and Peace Economics 16(4): 317-321.

Sandler T, Forbes JF (1980) Burden Sharing, Strategy and the Design of NATO. Economic Inquiry 18(3): 425-444.

Sandler T, Shimizu H (2014) NATO Burden Sharing 199-2010: An Altered Alliance. Foreign Policy Analysis 10(1): 43-60.

Solomon B (2004) NATO Burden Sharing Revisited. Defence and Peace Economics 15(3): 251-258.

Trading Economics 2000-2013. Population. Retrieved from: http://bit.ly/2c717PS. [Accessed 15March 2015]. 